\title{
Towards a New Specialization in Health Librarianship: LGBTQ Health
}

\author{
Martin Morris and Blake Wesley Hawkins
}

\section{Introduction}

In 1964, Canadian gay activist Jim Egan and Maclean's journalist Sidney Katz decided to kick-start a revolution [1]. Katz's two-part article "The Homosexual Next Door: A Sober Appraisal of a New Social Phenomenon," published by Maclean's in February and March of that year $[2,3]$, was the first positive portrayal of homosexuality to appear in the Canadian mass media [4]. Katz had worked closely with Egan on the milestone article, later recognised as lending critical mass to the nascent Canadian gay liberation movement. In the same year, Canada's first homophile organisation Association for Social Knowledge (ASK) was founded [5], and the gay community magazines Two and Gay were launched in Toronto [6].

There are various comprehensive accounts of the history of the struggle for LGBTQ (lesbian, gay, bisexual, transgender, queer/questioning) equality in Canada [7, 8], and the pages of JCHLA/JABSC are not the place to provide a further one. Indeed, readers of this article might be asking themselves what connection there is between Canadian gay activism and Canadian health librarianship. Our answer: because of a history of stigma and discrimination that may discourage them from accessing library services, LGBTQ health information seekers frequently have different information-seeking behaviours from their heterosexual peers. This includes LGBTQ health professionals $[9,10]$. In our view, it is impossible to understand these differences in information-seeking behaviour, or to respond appropriately, without understanding the corresponding history of discrimination that many LGBTQ people have experienced.

The current context for LGBTQ people, with dramatic improvements in civil rights and in public opinion, would be unimaginable to an LGBTQ person from 1964. However, many challenges remain such as ongoing workplace discrimination [11] and barriers to healthcare [12]. Here, we argue that the time has come for medical librarianship to engage more fully with the area of LGBTQ health and with potential LGBTQ users through visible demonstra- tions of support, the development of specialized training, and through the broadening of the evidence base for this area of our profession.

\section{A brief overview of LGBTQ health information from a Canadian perspective}

Canadians have played a pioneering role in the study of the health information needs of LGBTQ people, focussing largely on consumer health information to members of the public. After an early bibliography of the AIDS crisis [13], Creelman and Harris [14] were the first to research the information needs of nonheterosexual people, specifically lesbians living in Toronto. Joyce and Schrader's [15] subsequent examination of gay men's perceptions of the library system in Edmonton is another early example of its kind. Participants in both studies cited the library as their top source for information on health and coming out, but also complained of a negative impression of the responsiveness of the library to their particular needs.

It is now well established that various aspects of a person's social identity can strongly influence that person's information-seeking behaviour and (or) use of library services and in many cases can discourage the person from accessing those services. This may be, for example, due to the person's ethnicity [16] or their sexual orientation [17]. Health Canada's 2001 report Certain Circumstances [18] noted that even though a good source of LGBTQ health information may be available, cultural or other barriers may prevent users from accessing them. In the case of LGBTQ people, such barriers include a concern that they will experience discrimination, that they will have to out themselves, or that they will experience heteronormative attitudes from a librarian who won't understand their specific information needs. Although many LGBTQ people can rely on the support of their community when negotiating these barriers, it has been recently demonstrated [19] that the same barriers can be more daunting for many men who have sex with men (MSM), who may prefer not to

Martin Morris, MSc ${ }^{1}$, Liaison Librarian, Schulich Library of Science and Engineering, McGill University, 809 rue Sherbrooke ouest, Montréal, QC H3A 0C1.

Blake Wesley Hawkins, MLIS (Candidate), BA, School of Library, Archival and Information Studies, Irving K. Barber Learning Centre, University of British Columbia, 470 - 1961 East Mall, Vancouver, BC V6T 1Z1.

${ }^{1}$ Corresponding author (email: martin.morris@mcgill.ca) 
associate with the broader LGBTQ community due to an unwillingness to sexually identify as gay, homosexual, or bisexual; this information therefore has a higher "social cost" in the words of the author. Such people may therefore have only limited sources of information that they trust. A 2008 study into the information needs of Torontonians living with HIV/AIDS [20] demonstrates that people tend to seek information from sources they personally trust such as interpersonal sources and particularly from people who are like themselves.

The rise in electronic sources of information, and a lack of a physical location with a support network where LGBTQ people can talk about their personal concerns such as health, results in many going online to find information about different aspects of their health [21] or as a source of support that may be lacking at home or in their social circles. These networks may assume a long-term significance in the lives of LGBTQ people. However, as librarians are aware well beyond the confines of health librarianship, such online information seeking can be potentially problematic due to difficulties both in locating unbiased information and in adopting a critical attitude towards such information. A particularly pertinent example at the time of writing is pre-exposure prophylaxis (PrEP), a way for HIVnegative people to reduce their risk of infection by taking anti-HIV drugs on a regular basis. Although a favourable consensus on the use of PrEP is now rapidly developing within the LGBTQ community, it has been the subject of significant and often heated debate. Online information has been produced both by passionate PrEP advocates and by those who question whether PrEP is a responsible choice compared with condom use; as is common in such cases it can be difficult for many to locate reliable, neutral information without guidance.

The importance of libraries and librarians in the provision of consumer health information to LGBTQ people has long been recognised. During the early days of the AIDS crisis, J. Ingrid Lesley [22] made the following powerful observation:

What can libraries do? The heart of the question is this: Can libraries and librarians save lives? We believe so, because today, and quite possibly for many years to come, the only prevention for AIDS is information. Not to supply information, steadily, openly, daily to all library patrons, children as well as adults, is tantamount to withholding the only vaccine available for AIDS.

However, despite the acknowledged importance of libraries in health information work and the existence of research into the use of library services by LGBTQ people, there is a very definite lack of scholarship regarding the LGBTQ population within health librarianship. We are aware of only three articles, written in the early 2000 s, that aimed to cultivate awareness amongst health librarians about the unique health information needs of LGBTQ people and the challenges a health librarian might face in addressing these needs. Only one goes beyond consumer health to examine the information seeking of Canadian and American LGBTQ health professionals [9]. Flemming and Sullivant [23] discussed the availability of online guides for LGBTQ people at the start of the 21st century-we question whether such guides would have been practical for many patrons due to limited Internet access and the high cost of computer equipment at the time. The third discusses the politics and stigmatisation often related to being out as LGBTQ and the unique health challenges associated with their sexual orientation [24].

\section{A manifesto for Canadian LGBTQ health librarianship}

What can medical librarians do to demonstrate cultural competence and an openness and comfort with questions around LGBTQ health? In our view, the first step is to understand that despite the dramatically improved attitudes and civil rights now experienced by LGBTQ people in Canada, the struggle for LGBTQ equality is in fact far from over; many LGBTQ people continue to experience discrimination in their daily lives. This therefore has a significant impact on their information-seeking behaviour (i.e., the social cost). Within the context of healthcare, discrimination ranges from frequent and difficult to prove microaggressions to aggressive heteronormativity and systemic discrimination [25]. Some current examples include the refusal of Canadian Blood Services and Héma Québec to accept blood donations from men who have had sex with other men within the last five years [26], and the experiences of two-spirited people and transgender people of colour, who are not only at higher risk of violence [27, 28] but who also disproportionately experience discrimination and oppression when seeking healthcare $[29,30]$.

It has now been well demonstrated that these life experiences influence the decision of many LGBTQ people to seek healthcare from an LGBTQ health professional as they are considered to be very much less likely to behave in a discriminating or stigmatising way [31]. Fikar and Keith's research in 2004 [9], and a follow-up study conducted by one of the authors in 2014 [10], demonstrated that for similar reasons LGBTQ health professionals are considerably more likely to seek LGBTQ health information from a medical librarian who is also LGBTQ. With an understanding of this context, it becomes clear that anything medical libraries and librarians can do to demonstrate that they will welcome questions around LGBTQ health with understanding and without discrimination will be a step forward.

Medical librarians very much need options for training, which are currently lacking. We believe that the best way to develop this would be in collaboration with interested health professionals, perhaps through the modification of existing training already available to clinicians. Such training should cover the often complex language around sexual orientation and gender identity, an understanding of which is vital both in the framing of search strategies and in developing the rapport with the enquirer which is at the heart of every successful reference interview. Such training could take the form of Continuing Education modules at future Canadian Health Libraries Association/Association des bibliothèques de la santé du Canada (CHLA/ABSC) conferences, and it could also form part of the Medical 
Library Association's Academy of Health Information Professionals (AHIP) program.

Respondents to both Fikar and Keith's study [9], and to that conducted by one of the authors [10], highlighted the strong desire for potential LGBTQ patrons of medical libraries to see visible signs the library is willing to engage with the area of LGBTQ health. We would like to see more medical libraries, both academic and hospital, develop publicly visible tools such as subject guides, display signs of support on the library website, and promote links to LGBTQ health literature and resources. Opportunities also exist to work with interested organisations, such as university Queer/LGBTQ support groups, who are usually very willing to help partners raise LGBTQ awareness in their workplaces; this then serves to benefit the entire university and broader community.

Finally, we would like to see CHLA/ABSC have a significant role in the development of this emerging specialization in health librarianship. An excellent way to achieve this would be through the establishment of a new special interest group, comparable to the MLA's LGBTQ group, which would act as a network for discussing the issues facing LGBTQ patrons. This could be a space for producing social networks to gather feedback from LGBTQ and non-LGBTQ librarians. We would also welcome a special edition of $J C H L A / J A B S C$ on LGBTQ health information, similar to its past and very successful edition on Aboriginal health. This would encourage further research and program descriptions in an area which very much needs this, and could also serve as an introduction the current context of LGBTQ health information.

At a time when medical research into the specific health needs of LGBTQ people is increasing rapidly, we believe that health librarianship finds itself at an exciting crossroads. At the MLA/CHLA Mosaic/Mosaïque conference this coming May, we will be holding a special panel discussion comprised of medical librarians interested in exploring this emerging area of the profession, in developing training and awareness tools for interested colleagues, and in collaborating on increasing the evidence base available to interested health librarians. All of these are necessary steps to ensure that health librarianship fully serves its LGBTQ patrons and all those who seek unbiased LGBTQ health information.

\section{References}

1. Brewster H. Outcasts. The Walrus. 2014 June: 36-41.

2. Katz S. The homosexual next door: a sober appraisal of a new social phenomenon. Maclean's. 196422 February: 28-30.

3. Katz S. The Harsh Facts of Life in the 'Gay' World. Maclean's. 1964, 7 March;18:33-4.

4. McLeod DW. Lesbian and Gay Liberation in Canada: a selected annotated chronology. Toronto, ON: ECW Press/ Homewood Books; 1996. 302 p.

5. Canadian Gay and Lesbian Archives. Association for Social Knowledge (ASK): Canadian Gay and Lesbian Archives [Internet]. Toronto, ON: Canadia Gay and Lesbian Archives;
2012 [cited 5 Dec 2015]. Available from: http://clga.ca/ association-social-knowledge-ask

6. Toronto Public Library. 50 Years of Toronto Pride at the Toronto Public Library 2014 [Internet]. Toronto: Toronto Public Library; 2014 [cited 10 Dec 2015]. Available from: http://torontopubliclibrary.typepad.com/tr1/2014/06/50-yearsof-toronto-pride-at-the-toronto-reference-library.html

7. Smith M. Lesbian and Gay Rights in Canada: social movements and equality-seeking, 1971-1995. Toronto, ON: University of Toronto Press; 1999. 211 p.

8. Mazur P. Gay and lesbian rights in Canada: a comparative study. Int J Pub Admin. 2002;25(1):45-62. doi: 10.1081/PAD120006538 .

9. Fikar CR, Keith L. Information needs of gay, lesbian, bisexual, and transgendered health care professionals: results of an Internet survey. J Med Libr Assoc. 2004;92(1):56-65.

10. Morris M, Roberto KR. Information-seeking behaviour and information needs of LGBTQ health professionals: a followup study. Health Info Libr J. doi: 10.1111/hir.12139.

11. Pride at Work Canada. In \& out - diverging perspectives on LGBT inclusion in the workplace. Toronto, ON: Pride at Work Canada; 2015. 40 p.

12. Mitra S, Globerman J. Facilitators and barriers to health care for lesbian, gay and bisexual (LGB) people. Toronto, ON: Ontario HIV Treatment Network; 2014. 2 p.

13. McLeod DW, Miller AV. Medical, social and political aspects of the acquired immune deficiency syndrome (AIDS) crisis: a bibliography. Toronto, ON: Canadian Gay Archives; 1985. $314 \mathrm{p}$.

14. Creelman JA, Harris RM. Coming out: the information needs of lesbians. Collect Build. 1990;10(3/4):37-41. doi: $10.1108 / \mathrm{eb} 023281$.

15. Joyce S, Schrader AM. Hidden perceptions: Edmonton gay males and the Edmonton Public Library. Can J Info Libr Sci. 1997;22(1):19-37.

16. Caudra CA, Bates MJ. Library and information service needs of the nation. Proceedings of a Conference on the Needs of Occupational, Ethnic, and Other Groups in the United States. 1974.

17. Schaller S. Information needs of LGBTQ college students. Libri. 2011;61(2):100-15. doi: 10.1515/libr.2011.009.

18. McGill Centre for Applied Family Studies. Access to care: exploring the health and well-being of gay, Lesbian, bisexual and two-spirit people in Canada. In: Health Canada/Santé Canada, editor. "Certain circumstances" - issues in equity and responsiveness in access to health care in Canada. Ottawa, ON: Health Canada/Santé Canada; 2001. pp. 145-60.

19. Veinot TC, Meadowbrooke CC, Loveluck J, Hickok A, Bauermeister JA. How "community" matters for how people interact with information: mixed methods study of young men who have sex with other men. J Med Internet Res. 2013;15(2):e33. doi: 10.2196/jmir.2370.

20. O'Grady L. Meeting health information needs of people with HIV/AIDS: sources and means of collaboration. Health Info Libr J. 2008;25(4):261-9. doi: 10.1111/j.1471-1842. 2007.00764.x. 
21. Gray NJ, Klein JD, Noyce PR, Sesselberg TS, Cantrill JA. Health information-seeking behaviour in adolescence: the place of the internet. Soc Sci Med. 2005;60(7):1467-78.

22. Lesley JI. Libraries and the AIDS crisis: information is the only vaccine. In: American Library Association, editor. The ALA yearbook of library and information services. Chicago, IL: American Library Association; 1988. pp. 157-8.

23. Flemming T, Sullivant J. Consumer health materials for lesbians, gay men, bisexual and transgendered people. Pub Libr Q. 2000;18(3-4):95-107.

24. Perry G. Health information for lesbian/gay/bisexual/transgendered people on the internet: context and content. Inf Ref Serv Q. 2001;6(2):23-34.

25. Mulé NJ. Much to be desired: LGBT health inequalities and inequities in Canada. In: Fish J, Karban K, editors. Lesbian, gay, bisexual and trans health inequalities. Bristol, UK: Policy Press; 2015. pp. 27-44.

26. Canadian Blood Services. MSM policy [Internet]. Ottawa, ON: Canadian Blood Services; 2016 [cited 24 Jan 2016]. Available from: https://www.blood.ca/en/about-us/msm-policy
27. Bauer GR, Scheim AI, Pyne J, Travers R, Hammond R. Intervenable factors associated with suicide risk in transgender persons: a respondent driven sampling study in Ontario, Canada. BMC Pub Health. 2015;15:525. doi: 10.1186/s12889015-1867-2.

28. Amnesty International. Disappointing Senate decision exposes transgender people to threats and violence [Internet]. Ottawa, ON: Amnesty International; 2015 [cited 19 Jan 2016]. Available from: http://www.amnesty.ca/news/news-releases/ disappointing-senate-decision-exposes-transgender-people-tothreats-and-violence

29. Bauer G, Scheim A. Transgender people in Ontario, Canada. London, ON: TransPulse Project; 2015. 9 p.

30. Davidson T. A review of transgender health in Canada. Univ Ottawa J Med. 2015;5(2):40-5. doi: 10.18192/uojm.v5i2.1280.

31. Koester KA, Collins SP, Fuller SM, Galindo GR, Gibson S, Steward WT. Sexual healthcare preferences among gay and bisexual men: a qualitative study in San Francisco, California. PLoS One. 2013;8(8):e71546. doi: 10.1371/journal. pone.0071546. 